\title{
Effectivity of micro drainage system as part of macro drainage system: A case study of Kelapa Gading, North Jakarta
}

\author{
Ari Kusumawardhani ${ }^{1, *}$, Dwita Sutjiningsih ${ }^{1}$, and Evi Anggraheni ${ }^{1}$ \\ ${ }^{1}$ Department of Civil Engineering, Universitas Indonesia, Depok, Indonesia
}

\begin{abstract}
Flooding is one of the problems that Jakarta faces every year. To handle the issue, the government took action to build the East Flood Canal. The canal construction is expected to reduce flooding, especially in the east and north region of Jakarta. However, the construction did not make the area immediately free of flood risk. Previous study (Susanti, 2017) showed that even with the existence of the East Flood Canal, potential inundations may still happen, specifically in the Cakung Lama area. In 2017, there were still several inundation points in the Sunter area, especially in Kelapa Gading. This research aims to identify the cause of inundations in the area by evaluating channel capacity in the micro drainage system in Kelapa Gading using hydrological model HEC-RAS 4.1.0 and WinTR. The simulation results showed that several channels in the system cannot accommodate the inflow, hence causing inundation in some areas in the Kelapa Gading area. According to the simulation results, it can be concluded that the micro drainage system in Kelapa Gading is not effective to accommodate the inflow.
\end{abstract}

\section{Introduction}

Flooding occurs in Jakarta every year [1]. A large scale of floods occurs approximately once every five years in the Ciliwung River Basin [2]. To deal with the problem, one of the actions taken by the government was construction of East Flood Canal. The construction of the East Flood Canal is predicted to reduce the inundation area in Jakarta [3].

The development of the East Flood Canal does not directly make the service area into a flood-free area. The scale of flood impacts has significantly increased in the last few decades [4]. The result of the previous study on the macro drainage system in the service area of the East Flood Canal showed that the cause of the inundation in the area is not because of the system. The macro drainage system in the East Flood Canal is still able to accommodate its design peak discharge [5].

However, in recent years we can still find inundations in the service area of the East Flood Canal, such as in Sunter Basin, primarily in Kelapa Gading. To determine the cause of the inundation in the Sunter Basin, further study is needed. Continuing the previous

${ }^{*}$ Corresponding author: arikusumawardhani@yahoo.com 
research about the macro drainage System in the East Flood Canal, the purpose of this study is to determine whether the cause of the inundation that occurs was because of its micro drainage system by using HEC-RAS 4.1.0 and WinTR-20 to calculate its effectivity.

\section{Research method}

The selected study area is located in Kelapa Gading, North Jakarta. The data used in this study are mostly obtained from the previous study. Some data, such as channels crosssection, are obtained from field surveys. To achieve the geographical data of the study area, such as land cover, length, and area, a program with geographic information system is needed. ArcGIS 10.1, a software from ESRI, is used to find geographical data from the study area. ArcGIS is a commercial software of geographic information systems, and the spatial information and its characteristics can accurately and fully be output to users regarding texts or pictures according to specified needs [6].

The rainfall calculation is done based on rain gages that affect the study area. Rainfall data used were from two rain gages in Tanjung Priok and Kemayoran. The annual maximum daily rainfall was identified for 13 years (2005-2017). The relative weights for each gage were determined using Thiessen Polygon. The average areal precipitation will be used to design rainfall using Log Pearson type III and Gumbel distribution.

In this study, WinTR-20 ver 3.10 and HEC-RAS 4.1.0 are used. WinTR-20 ver 3.10 is a computer program to assist the engineer in the hydrologic evaluation of flood event for use in analysis of water resource projects. It is a physically-based event model which computes direct run-off resulting from any synthetic or natural rainstorm [7]. WinTR-20 ver 3.10 is an SCS-CN based program to simulate the rainfall run-off modeling that can represent the spatial condition of watershed properties. Since the spatial distribution has a significant effect on the hydrological responses [8], this model can describe the effect of spatial distribution of land use variability at Upper Ciliwung Watershed [9]. The outputs of WinTR-20 ver 3.10 are the peak flow for each sub-area, and this will be used as input on HEC-RAS 4.1.0. HEC-RAS 4.1.0 (Hydrologic Engineering Software-River Analysis System) is developed by Corps' Civil Works Hydrologic Engineering Research and Development Program. HEC-RAS 4.1.0 is a one-dimensional flow model which is capable of performing calculation of steady flow, unsteady flow, and movable boundary sediment and water quality analysis for a network of natural or constructed channels [10].

The result of the HEC-RAS 4.1.0 simulation will show the comparison between the water level based on the peak flow from WinTR-20 ver 3.10 with the existing channel profile. The result will show the area in which design flood discharge exceeds the existing channel capacity of the channel (overflow). Then, the effectivity of the micro drainage system is calculated. It can be said that the effectivity is $100 \%$ effective if the capacity of the channel exceeds its peak flow. If not, the effectivity can be calculated by Eq. 1:

$$
\text { Effectivity }=(\text { Capacity of the Channel/Peak flow }) \times 100 \%
$$

If the effectivity is less than $100 \%$, then it can be said that the existing channel cannot accommodate the flood discharge and causes an inundation. From these results, it is hen seen whether the cause of the flooding area is caused by the micro drainage system.

\section{Results and discussion}

Simulations were conducted in two models, for Kodamar and Kelapa Gading area. Each area consists of several sub-areas. Kodamar consists of two sub-areas, SubK1 and SubK2. Kelapa Gading consists of eight sub-areas, Sub-area 1 to Sub-area 8 (Fig. 1). 


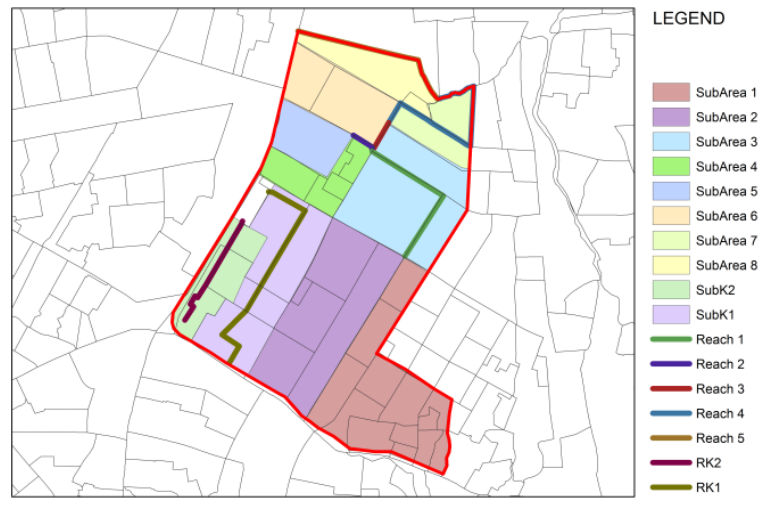

Fig. 1. Sub-areas of kelapa gading sub watershed.

Table 1. Sub-area properties data.

\begin{tabular}{|c|c|c|c|c|c|c|}
\hline Sub-area & Area (Ha) & Location & $\mathbf{L}(\mathbf{m})$ & $\mathbf{A}\left(\mathbf{m}^{2}\right)$ & $\mathbf{n}$ & $\mathbf{C N}$ \\
\hline \multirow{3}{*}{ Sub-area 1} & \multirow{3}{*}{163.78} & Jl. Boulevard Selatan & 1915.2 & 9.64 & 0.025 & \multirow{3}{*}{85} \\
\hline & & Jl. Kelapa Puan Raya & 208.27 & 10.80 & 0.025 & \\
\hline & & Jl. Kelapa Kopyor & 1010 & 6.94 & 0.025 & \\
\hline Sub-area 2 & 160.33 & Jl. Kelapa Puan Raya & 882.9 & 10.80 & 0.025 & 86 \\
\hline \multirow{2}{*}{ Sub-area 3} & \multirow{2}{*}{135.37} & Jl. Pelepah Raya & 873.3 & 10.05 & 0.025 & \multirow{2}{*}{85} \\
\hline & & Jl. Kelapa Nias & 1770.1 & 10.23 & 0.025 & \\
\hline \multirow{2}{*}{ Sub-area 4} & \multirow{2}{*}{47.15} & Jl. Artha Gading & 1400.0 & 10.58 & 0.025 & \multirow{2}{*}{90} \\
\hline & & Jl. Boulevard Barat & 244.8 & 1.10 & 0.017 & \\
\hline Sub-area 5 & 41.32 & Jl. Artha Gading & 864.3 & 10.58 & 0.025 & 92 \\
\hline Sub-area 6 & 71.37 & Jl. Perum. Gading Kirana & 325.2 & 5.55 & 0.025 & 88 \\
\hline \multirow{4}{*}{ Sub-area 7} & \multirow{4}{*}{43.26} & Jl. Gading Kirana & 250.5 & 34.88 & 0.025 & \multirow{4}{*}{84} \\
\hline & & Jl. Kelapa Hibrida & 889.1 & 11.20 & 0.025 & \\
\hline & & Jl. Boulevard Utara & 653.7 & 13.75 & 0.025 & \\
\hline & & Kali Betik Pertamina & 433.4 & 29.20 & 0.025 & \\
\hline Sub-area 8 & 51.00 & Jl. Tanah Merah & 787.7 & 0.33 & 0.017 & 84 \\
\hline \multirow{3}{*}{ SubK1 } & \multirow{3}{*}{124.31} & Jl. Gading Raya & 1295 & 7.20 & 0.017 & \multirow{3}{*}{81} \\
\hline & & Jl. Bangka & 850 & 13.23 & 0.025 & \\
\hline & & J1. Pulau Putri & 425 & 32.13 & 0.025 & \\
\hline SubK2 & 56.632 & Jl. Tabah Raya & 1240 & 9.28 & 0.017 & 83 \\
\hline
\end{tabular}


Based on Fig. 1, using Arc-GIS 10.1, the properties data of each sub-area can be acquired, as in Table 1. It is essential to determine the properties' data of each sub-area to determine the amount of surface run-off of each sub-area. The properties of each sub-area will be used as the input data of WinTR-20 to produce the peak discharge for the selected return period.

Table 2. Result of Thiessen Polygon method.

\begin{tabular}{|c|c|c|}
\hline & Area (Ha) & Percentage (\%) \\
\hline Tanjung Priok & 158.76 & 17.54 \\
\hline Kemayoran & 746.49 & 82.46 \\
\hline Total & 905.25 & 100 \\
\hline
\end{tabular}

The relative weight for each rain gage is determined using Thiessen Method. The result of this calculation can be seen in Table 2 . We can see that $83.46 \%$ of the study area is affected by the rain gage in Kemayoran and $17.54 \%$ by rain gage in Tanjung Priok. The average areal precipitation for the Kelapa Gading area can be seen in Table 3.

Table 3. Areal average precipitation Kelapa Gading.

\begin{tabular}{|l|l|}
\hline Time & Precipitation (mm) \\
\hline 2005 & 81 \\
\hline 2006 & 72 \\
\hline 2007 & 69 \\
\hline 2008 & 84 \\
\hline 2009 & 87 \\
\hline 2010 & 79 \\
\hline 2011 & 68 \\
\hline 2012 & 78 \\
\hline 2013 & 69 \\
\hline 2014 & 71 \\
\hline 2015 & 278 \\
\hline 2016 & 125 \\
\hline 2017 & 180 \\
\hline
\end{tabular}

From the data above, the design rainfall with 2, 5, 10 and 25 year return period can be calculated using the Log Pearson Type III distribution and Gumbel distribution. Then, the Goodness of Fit test is conducted using the Chi-Square Test and Smirnov-Kolmogorov Test. The purpose of the test is to determine which distribution will be used in the next calculation. The result of the calculation can be seen in Table 4 . 
Table 4. Summary of the result of rainfall data calculation.

\begin{tabular}{|c|c|c|c|}
\hline \multirow{2}{*}{ No } & \multirow{2}{*}{$\begin{array}{l}\text { Return } \\
\text { Period }\end{array}$} & \multicolumn{2}{|c|}{ Design Rainfall (mm) } \\
\hline & & Gumbel Method & Log Pearson Type III Method \\
\hline 1 & 2 & 75.654 & 65.54 \\
\hline 2 & 5 & 131.192 & 97.55 \\
\hline 3 & 10 & 168.038 & 130.73 \\
\hline 4 & 25 & 214.597 & 191.63 \\
\hline \multicolumn{4}{|c|}{ Chi Square Test } \\
\hline \multicolumn{2}{|c|}{ Chi- Critical } & 5.991 & 5.991 \\
\hline \multicolumn{2}{|c|}{$\begin{array}{c}\text { Chi- } \\
\text { Calculation }\end{array}$} & 0.461 & 0.461 \\
\hline \multicolumn{2}{|c|}{ Hypothesis } & Accepted & Accepted \\
\hline \multicolumn{4}{|c|}{ Smirnov-Kolmogorov Test } \\
\hline \multicolumn{2}{|c|}{$\Delta$ Critical } & 0.368 & 0.368 \\
\hline \multicolumn{2}{|c|}{$\Delta \mathbf{M a x}$} & 0.237 & 0.206 \\
\hline \multicolumn{2}{|c|}{ Hypothesis } & Accepted & Accepted \\
\hline
\end{tabular}

The results of both tests show that the calculation of both distributions is acceptable. But, for the next step, the Log Pearson Type III distribution will be used because its $\Delta$ Max is smaller than the Gumbel Method. The design rainfall will be used as the inputs for the WinTR-20 along with the properties of each sub-area. The output from WinTR-20 simulation will be a peak flow from each return period. It can be seen in Table 5 .

The peak flow will be used as the inputs for HEC-RAS 4.1.0 simulation. The result from HEC-RAS 4.1.0 simulation will show which channels are still able to accommodate the design peak flow and which channels are not.

Fig 2. The blue line represents the water level from the five-year return period peak flow, the red one is the 10 year return period, and the green one represents the 25 year return period peak flow. The results obtained from the simulation are then analyzed to determine whether the result is following what is happening in the real event. The result can determine the factor of the occurrence of the flood as to whether it caused by the micro drainage system or not. The next thing to do is to calculate the effectiveness of the channel by comparing the existing capacity of the micro drainage system with the peak flow of each return period.

A micro drainage channel should be able to accommodate its 10 year return period peak flow. From Table 6, it can be seen that six channels cannot accommodate its peak flow. From that, it can be concluded that the inundation in Kelapa Gading Area caused by the micro drainage channel cannot accommodate the discharge. 
Table 5. Peak time simulation result for each sub-area and reaches.

\begin{tabular}{|c|c|c|c|}
\hline Location & Q5 $\left(\mathbf{m}^{3} / \mathbf{s}\right)$ & $\mathrm{Q10}\left(\mathbf{m}^{3} / \mathbf{s}\right)$ & $\mathrm{Q} 25\left(\mathrm{~m}^{3} / \mathrm{s}\right)$ \\
\hline Sub-area 1 & 5.8 & 8.2 & 12.5 \\
\hline Sub-area 2 & 5.2 & 7.5 & 11.8 \\
\hline Sub-area 3 & 5.1 & 7.2 & 11.0 \\
\hline Sub-area 4 & 3.9 & 5.5 & 8.2 \\
\hline Sub-area 5 & 3.6 & 5.0 & 7.3 \\
\hline Sub-area 6 & 8.6 & 12.1 & 18.1 \\
\hline Sub-area 7 & 1.5 & 2.2 & 3.3 \\
\hline Sub-area 8 & 7.5 & 10.5 & 15.4 \\
\hline Reach 1 Upstream & 11.0 & 15.7 & 24.2 \\
\hline Reach 1 Downstream & 10.1 & 15.0 & 23.3 \\
\hline Reach 2 Upstream & 3.6 & 5.0 & 7.3 \\
\hline Reach 2 Downstream & 3.4 & 4.8 & 7.1 \\
\hline Reach 3 Upstream & 18.8 & 27.1 & 41.6 \\
\hline Reach 3 Downstream & 18.5 & 26.9 & 41.4 \\
\hline Reach 4 Upstream & 21.8 & 31.4 & 48 \\
\hline Reach 4 Downstream & 19.4 & 28.3 & 44.3 \\
\hline Reach 5 Upstream & 20.8 & 30.3 & 47.4 \\
\hline Reach 5 Downstream & 18.7 & 27.8 & 45.3 \\
\hline Outlet Kelapa Gading & 21.0 & 30.9 & 49.1 \\
\hline SubK1 & 8.2 & 12.3 & 20 \\
\hline SubK2 & 5.1 & 7.4 & 11.7 \\
\hline RK 1 Upstream & 8.2 & 12.3 & 20 \\
\hline RK 1 Downstream & 7.4 & 11.1 & 18 \\
\hline RK 2 Upstream & 5.1 & 7.4 & 11.7 \\
\hline RK 2 Downstream & 4.5 & 6.6 & 10.6 \\
\hline Outlet Kodamar & 11.3 & 16.9 & 27.6 \\
\hline
\end{tabular}




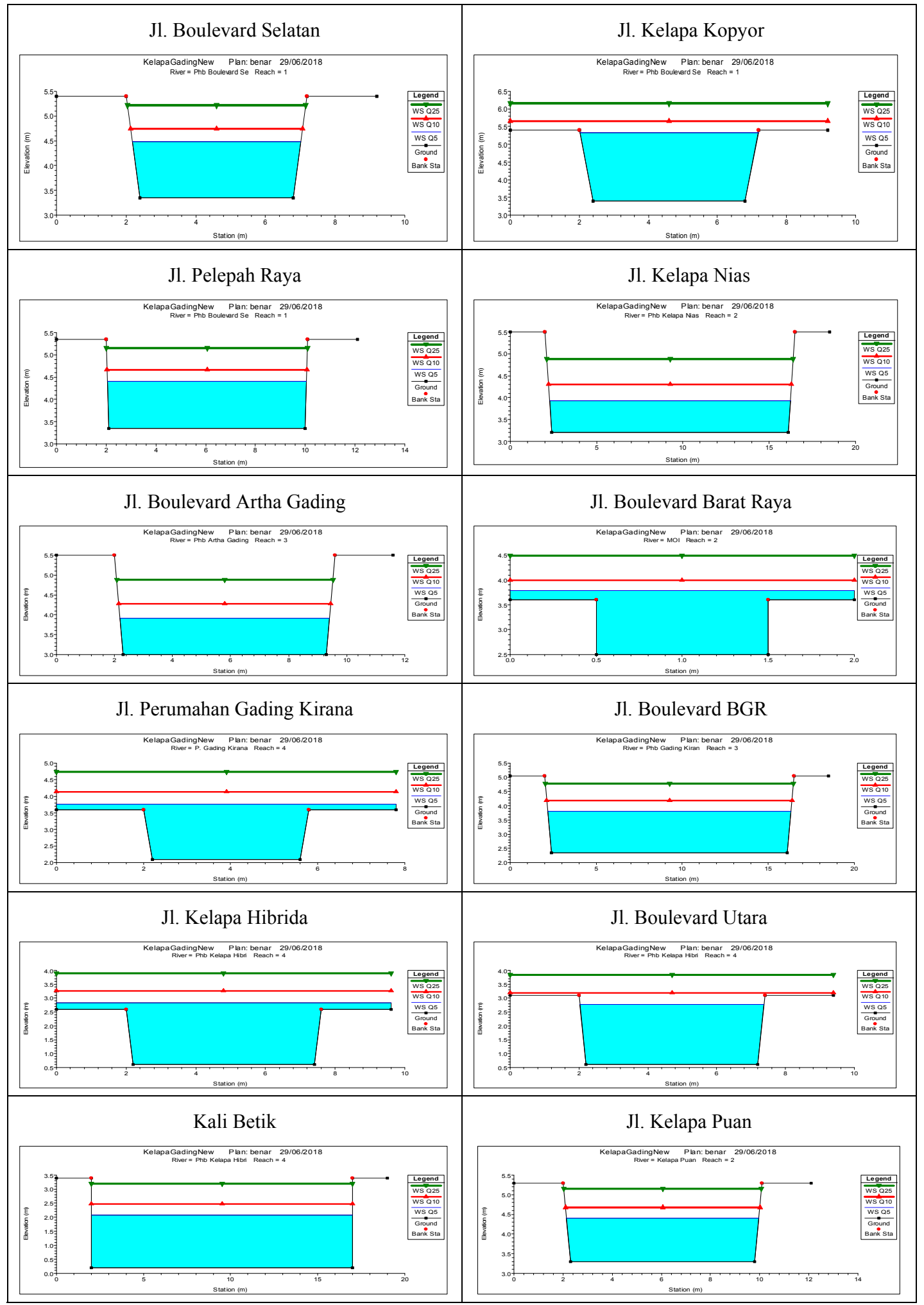




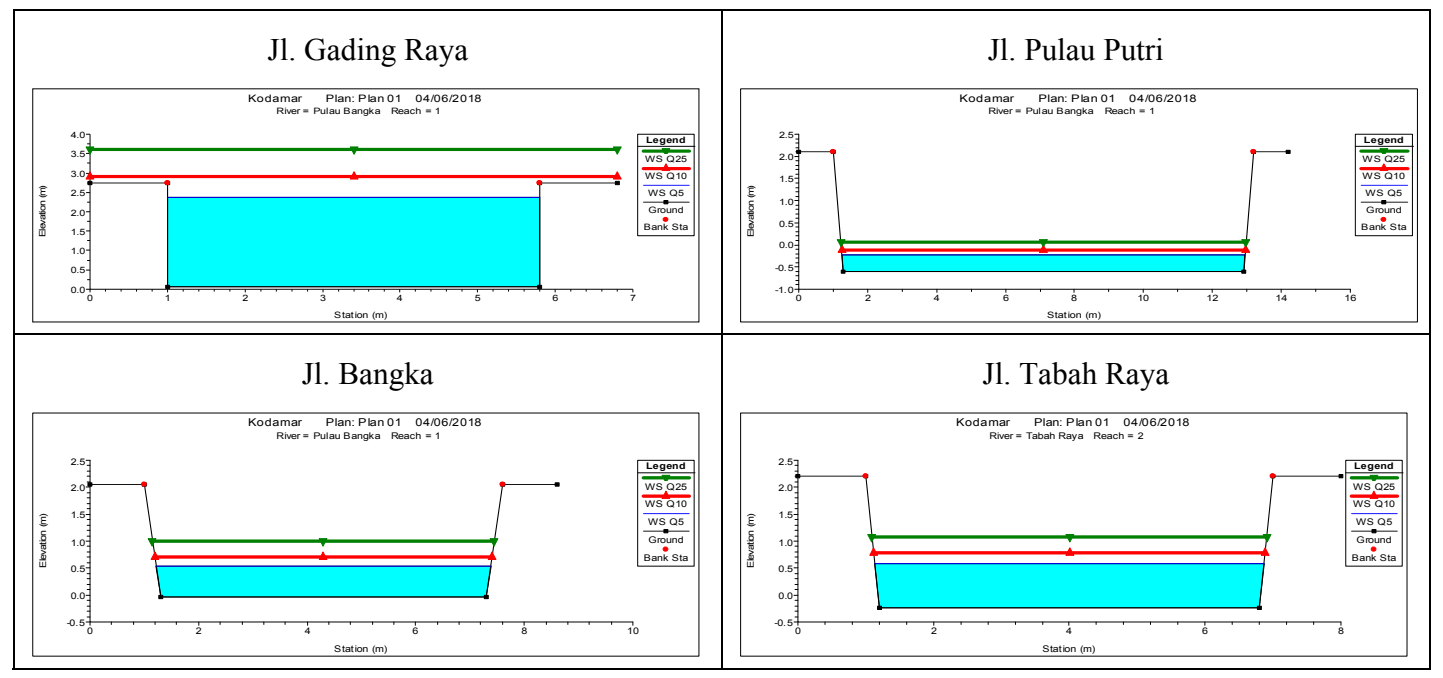

Fig. 2. The result of HEC-RAS 4.1.0 simulation.

Table 6. Peak time simulation result for each sub-area and reaches.

\begin{tabular}{|c|c|c|c|c|}
\hline Location & Capacity ( $\mathbf{m}^{\mathbf{3} / \mathbf{s})}$ & $\mathbf{Q ~ 5}$ & $\mathbf{Q} \mathbf{1 0}$ & $\mathbf{Q} \mathbf{2 5}$ \\
\hline Jl. Boulevard Selatan & 13.32 & $100 \%$ & $100 \%$ & $100 \%$ \\
\hline Jl. Kelapa Kopyor & 8.10 & $100 \%$ & $99 \%$ & $65 \%$ \\
\hline Jl. Kelapa Puan Raya & 14.46 & $100 \%$ & $100 \%$ & $100 \%$ \\
\hline Jl. Pelepah Raya & 13.25 & $100 \%$ & $100 \%$ & $100 \%$ \\
\hline Jl. Kelapa Nias & 13.08 & $100 \%$ & $100 \%$ & $100 \%$ \\
\hline Jl. Boulevard Artha Gading & 14.36 & $100 \%$ & $100 \%$ & $100 \%$ \\
\hline Jl. Boulevard Barat Raya & 3.8 & $97 \%$ & $69 \%$ & $46 \%$ \\
\hline Jl. Perum. Gading Kirana & 6.37 & $74 \%$ & $53 \%$ & $35 \%$ \\
\hline Jl. Boulevard BGR & 68.24 & $100 \%$ & $100 \%$ & $100 \%$ \\
\hline Jl. Kelapa Hibrida & 16.13 & $74 \%$ & $51 \%$ & $34 \%$ \\
\hline Jl. Boulevard Utara & 21.47 & $100 \%$ & $68 \%$ & $45 \%$ \\
\hline Kali Betik Pertamina & 50.58 & $100 \%$ & $100 \%$ & $100 \%$ \\
\hline Jl. Gading Raya & 8.634 & $100 \%$ & $70 \%$ & $43 \%$ \\
\hline Jl. Bangka & 19.903 & $100 \%$ & $100 \%$ & $100 \%$ \\
\hline Jl. Pulau Putri & 62.127 & $100 \%$ & $100 \%$ & $100 \%$ \\
\hline Jl. Tabah Raya & 12.161 & $100 \%$ & $100 \%$ & $100 \%$ \\
\hline
\end{tabular}




\section{Conclusions}

It can be seen from the result of HEC-RAS 4.1.0 simulation and the calculation of effectivity that part of the micro drainage channel cannot accommodate the peak flow. These are channels in Jl. Kelapa Kopyor, Jl. Boulevard Barat Raya, Jl. Perumahan Gading Kirana, Jl. Kelapa Hibrida, Jl. Boulevard Utara and Jl. Gading Raya. From the results, it can be concluded that the inundation in the Kelapa Gading area happens because the micro drainage channel cannot accommodate the discharge (overflow).

This research is supported by research funds made available through the Research Fund of PITTA (Publikasi Terindeks Internasional Untuk Tugas Akhir Mahasiswa UI) of Universitas Indonesia, 2018. (No. 2423/UN2.R3.1/HKP.05.00/2018)

\section{References}

1. J.J. Brinkman, M. Hartman, Jakarta flood hazard mapping framework (2009)

2. Dir. General of Water Resources, Comprehensive flood management plan (Ministry of Public Works, Republik Indonesia, 2013)

3. Tim Mirah Sakethi, Mengapa Jakarta banjir (2010)

4. Y. Budiyono, J.C.J.H. Aerts, D. Tollenar, P.J. Ward, Nat. Hazards Earth Syst. Sci, 16 (2016)

5. N. Susanti, Impact of eastern flood canal towards to macro drainage system performance in eastern flood canal service area at East Jakarta and North Jakarta (to be published)

6. Y. Cheng, J. Zhanga, J. Peng, J. of Rock Mechanics and Geotech. Eng. 5 (2013)

7. USDA, TR-20 Computer program for project formulation hydrology (NRCS, 1992)

8. E. Anggraheni, D. Sutjiningsih, I. Emmanuel, O. Payratre, H. Andrieu, Int. J. of Tech. (2018)

9. S. Murniningsih, E. Anggraheni, ARPN J. of Eng. and Appl. Sci. (2016)

10. United States Army Corps of Engineers (USACE), Hydraulic reference manual v.4.1. (Hydraulic Engineering Center, USA, 2010) 